\title{
Effects of Dietary Protein on Body Composition in Exercising Individuals
}

\author{
Jose Antonio 1,*®D, Darren G. Candow ${ }^{2}$, Scott C. Forbes ${ }^{3}$, Michael J. Ormsbee ${ }^{4,5}$, \\ Patrick G. Saracino ${ }^{4}$ and Justin Roberts ${ }^{6} \mathbb{C D}$ \\ 1 Department of Health and Human Performance, Nova Southeastern University, Davie, FL 33314, USA \\ 2 Faculty of Kinesiology and Health Studies, University of Regina, Regina, SK S4S0A2, Canada; \\ Darren.candow@uregina.ca \\ 3 Faculty of Education, Department of Physical Education, Brandon University, Brandon, MB R7A6A9, \\ Canada; forbess@brandonu.ca \\ 4 Department of Nutrition, Food \& Exercise Sciences, Institute of Sports Sciences \& Medicine, Florida State \\ University, Tallahassee, FL 32313, USA; mormsbee@fsu.edu (M.J.O.); pgs16@my.fsu.edu (P.G.S.) \\ 5 Discipline of Biokinetics, Exercise and Leisure Sciences, University of KwaZulu-Natal, Durban 4041, \\ South Africa \\ 6 Cambridge Centre for Sport and Exercise Sciences, Anglia Ruskin University, Cambridge CB11PT, UK; \\ Justin.roberts@anglia.ac.uk \\ * Correspondence: Jose.Antonio@nova.edu; Tel.: +1-561-239-1754
}

Received: 3 June 2020; Accepted: 19 June 2020; Published: 25 June 2020

\begin{abstract}
Protein is an important component of a healthy diet and appears to be integral to enhancing training adaptations in exercising individuals. The purpose of this narrative review is to provide an evidence-based assessment of the current literature examining increases in dietary protein intake above the recommended dietary allowance (RDA: $0.8 \mathrm{~g} / \mathrm{kg} / \mathrm{d}$ ) in conjunction with chronic exercise on body composition (i.e., muscle, fat and bone). We also highlight acute and chronic pre-sleep protein studies as well as the influence of exercise timing on body composition. Overall, a high-protein diet appears to increase muscle accretion and fat loss and may have beneficial effects on bone when combined with exercise. Pre-sleep protein is a viable strategy to help achieve total daily protein goals. Importantly, there appears to be no deleterious effects from a high-protein diet on muscle, fat or bone in exercising individuals.
\end{abstract}

Keywords: exercise; diet; amino acids; training

\section{Introduction}

Protein is an important component of a healthy diet and is essential for growth and development. Inadequate dietary protein, even with adequate caloric intake, will result in malnutrition [1]. Beyond health, dietary protein intake appears to be integral for exercising individuals [2-7]. Despite scientific inquiry by von Liebig in 1842 [8], it has only become increasingly evident in recent decades that protein requirements are elevated above the recommended dietary allowance (RDA) of $0.8 \mathrm{~g} / \mathrm{kg} / \mathrm{d}$ [9]. These greater dietary protein needs may be associated with exercise-induced mitochondrial biogenesis, protein synthesis, and endocrine and immune responses $[5,10]$. The purpose of this brief narrative review is to examine the efficacy and safety of increasing dietary protein intake in trained individuals, as well as the acute and chronic effects of pre-sleep protein on body composition. Lastly, we evaluate the current scientific literature pertaining to increasing protein intake on bone. 


\section{Dietary Protein and Body Composition in Trained Individuals}

For individuals who exercise regularly, the current body of evidence supports dietary protein needs 1.5- to 2.0-fold higher than the RDA of $0.8 \mathrm{~g} / \mathrm{kg} / \mathrm{d}$ [4-6,10,11]. It is important to note that these elevated dietary protein requirements and recommendations are for individuals performing chronic exercise ( $>3$ months) [9]. Gontzea et al. was the first to demonstrate an increased protein requirement, based on a negative shift in whole-body nitrogen balance, in participants initiating an exercise training program and ingesting a constant protein intake of $1.0 \mathrm{~g} / \mathrm{kg} / \mathrm{d}$ [12]. As such, the primary emphasis of this section will be on studies examining dietary protein needs for chronic exercising individuals. Thus, sedentary, unhealthy, or inactive populations performing short-term training ( $<3$ months) will not be discussed; for clinical trials discussing sedentary populations, see the following references [13-16].

High-protein diets may assist with fat mass reduction through a variety of mechanisms including enhanced resting and sleeping energy expenditure [17], elevated activity related energy expenditure, increases in non-exercise activity thermogenesis $[18,19]$ and a greater thermic effect of feeding relative to other macronutrients $[20,21]$. Furthermore, it is well known that protein feeding acutely elevates muscle protein synthesis post-exercise [22-29], which in theory should result in greater muscle protein accretion over time. However, caution is required when extrapolating these 'snap-shot' findings to whole-body adaptations [30]. In addition, it is important to note that these acute feeding studies are rigorously controlled (i.e., performed in a fasted state, single-protein-only dose) to enhance internal validity; however, the generalizability (i.e., external validity) of these studies in free-living humans consuming mixed meals multiple times a day may be limited. As such, longitudinal controlled trials may be the ideal methodology to determine whether protein doses above the RDA can impact body composition.

Kerksick et al. [31] assessed the effects of a 10 week ( $4 \mathrm{~d} / \mathrm{wk})$ resistance training program in conjunction with whey protein supplementation on body composition, muscular strength, muscular endurance, and anaerobic capacity. Resistance-trained males $(N=36)$ received either $48 \mathrm{~g} / \mathrm{d}$ of carbohydrate (placebo), or $40 \mathrm{~g} / \mathrm{d}$ of whey protein $+8 \mathrm{~g} / \mathrm{d}$ of casein (WC), or $40 \mathrm{~g} / \mathrm{d}$ of whey protein $+3 \mathrm{~g} / \mathrm{d}$ of branched-chain amino acids $+5 \mathrm{~g} / \mathrm{d}$ of L-glutamine (WBG). There were no differences between groups for energy intake, training volume, blood parameters, anaerobic capacity, or muscular strength. WC experienced the greatest increases in lean body mass (as assessed by dual energy $\mathrm{x}$-ray absorptiometry; DXA), possibly due to the higher complete protein (whey and casein) intake [31]. Ormsbee et al. examined protein supplementation on muscular strength and body composition during a 6 month $(5 \mathrm{~d} / \mathrm{wk})$ concurrent strength and endurance training program in sedentary men and women [32]. Participants $(N=51 ; 26$ males, 25 females; age 18-25 yr) were randomized to a protein (PRO; $42 \mathrm{~g} /$ serving) or carbohydrate $(\mathrm{CON})$ supplement twice daily. Females in both groups similarly improved lean body mass, one-repetition maximum (1-RM) bench press and hip sled strength. Importantly, females supplementing with PRO experienced a greater reduction in fat mass than CON (PRO: $-1.7 \pm 0.5 \mathrm{~kg}$ vs. CON: $0.1 \pm 0.5 \mathrm{~kg}$ ). Males experienced similar changes in body composition [32].

In a series of studies, Antonio et al. examined the impact of high-protein diets with and without alterations in habitual training $[33,34]$. The first study included trained $(N=30)$ males and females consuming $4.4 \mathrm{~g} / \mathrm{kg} / \mathrm{d}$ of protein for eight weeks and reported no changes in body mass, muscle or fat mass. Participants were instructed not to change their habitual training throughout the study. Thus, the follow-up study assessed a high-protein diet $(3.4 \mathrm{~g} / \mathrm{kg} / \mathrm{d})$ in conjunction with a periodized heavy resistance-training program [34]. Participants $(N=48)$ in the control and high-protein groups were instructed to consume $\sim 2$ and $>3 \mathrm{~g} / \mathrm{kg} / \mathrm{d}$ of dietary protein, respectively. Despite the high-protein group consuming more calories ( $\sim 495 \mathrm{kcals} / \mathrm{d})$, they experienced a greater decrease in fat mass $(-1.6 \mathrm{~kg})$ compared to control $(-0.3 \mathrm{~kg})$. On the other hand, the high-protein $(+1.5 \mathrm{~kg})$ and control groups $(+1.5 \mathrm{~kg})$ gained a similar amount of lean body mass. Furthermore, no deleterious effects were reported in either group [34]. Similarly, Campbell et al. randomized aspiring female physique competitors $(N=17)$ to a high-protein $(2.5 \mathrm{~g} / \mathrm{kg} / \mathrm{d})$ and low-protein $(0.9 \mathrm{~g} / \mathrm{kg} / \mathrm{d}$, similar to the RDA: $0.8 \mathrm{~g} / \mathrm{kg} / \mathrm{d})$ diet in conjunction with 8 weeks of resistance training [35]. Following training, fat-free mass increased 
more in the high-protein group $(2.1 \mathrm{~kg})$ compared with the low-protein group $(0.9 \mathrm{~kg}) . \mathrm{In}$ addition, fat mass decreased more in the high-protein group $(-1.1 \mathrm{~kg})$ compared to the low-protein group $(-0.7 \mathrm{~kg})$. There were no differences in strength changes between groups [35]. Thus, protein intakes greater than twice the RDA may improve body composition in trained individuals that alter their training regimen. Furthermore, the addition of protein ( $31 \mathrm{~g} / \mathrm{d}$ of milk protein) in physically active older adults (67-73 yr) with relatively low habitual dietary protein consumption $(<1 \mathrm{~g} / \mathrm{kg} / \mathrm{d})$ increased lean body mass and reduced fat mass over a 12 week period compared to those who did not augment their diet with additional protein [36]. In addition, whey protein supplementation $(77 \mathrm{~g} / \mathrm{d})$ in military participants increased upper-body muscle endurance and decreased fat mass over 8 weeks

In contrast, there have been several studies showing no benefit from a higher dietary protein intake. In novice bodybuilders $(N=12 ; 22 \mathrm{yr})$ engaged in their initial stages of training, a high protein intake of $2.62 \mathrm{~g} / \mathrm{kg} / \mathrm{d}$ compared to $1.35 \mathrm{~g} / \mathrm{kg} / \mathrm{d}$ did not alter muscle mass or strength gains over 3.5 weeks [37]. Antonio et al. also found no effect from either 2.6 to $3.3 \mathrm{~g} / \mathrm{kg} / \mathrm{d}$ of protein during resistance training on body composition in resistance-trained young males [38,39]. Spillane and Willoughby randomized $(N=21)$ resistance-trained males to either a protein $(94 \mathrm{~g} / \mathrm{d})$ plus carbohydrate $(196 \mathrm{~g} / \mathrm{d})$ or carbohydrate alone for 56 days and found no differences between groups over time on body composition [40]. In a cross-sectional study, collegiate strength/power athletes $(N=23)$ performed 12 weeks of resistance training in which they were stratified into three groups based on habitual daily protein intake below recommended levels (BL; $1.0-1.4 \mathrm{~g} / \mathrm{kg} / \mathrm{d} ; n=8)$, recommended levels (RL; $1.6-1.8 \mathrm{~g} / \mathrm{kg} / \mathrm{d} ; n=7)$ and above recommended levels ( $\mathrm{AL} ;>2.0 \mathrm{~g} / \mathrm{kg} / \mathrm{d} ; n=8)$. There were no changes in body mass, lean body mass or fat mass in any group and similar improvements in 1-RM bench press and 1-RM squats between groups [41]. Collectively, there appears to be a small but beneficial effect of a high protein intake ( $\geq 2 x$ the RDA) on lean body mass and in trained individuals. This is in agreement with a recent systematic review, meta-analysis, and meta-regression [42]. Morton et al. assessed data from 49 studies with 1863 participants and found that protein supplementation significantly increased fat-free mass as well as muscle fiber cross-sectional area [42]. Conversely, there is limited data to suggest that protein supplementation may promote a loss of fat mass. Thus, the pragmatic approach regarding dietary protein recommendations should err on the higher side of intake (i.e., at least twice as much as the RDA and perhaps even higher). Further, importantly, increasing dietary protein intake had no deleterious effects. Future research should clarify what the upper limit of protein intake might be regarding gains in lean body mass; conversely, it is possible that the amount of protein that is required for lean body mass accretion may not be the same as what is needed for the loss of fat mass.

\section{Pre-sleep Protein}

In trained individuals, consuming low-energy protein-centric food items prior to sleep provides an opportunity to increase energy intake, support the muscle repair process, and provide an additional time to achieve total daily protein goals [43-45]. The purpose of this section is to summarize the acute and chronic effects of pre-sleep protein as well as discuss the impact of exercise timing in relation to pre-sleep protein on body composition changes.

\subsection{Acute Dosing}

Multiple studies indicate that pre-sleep protein "meals" have either a beneficial or no significant impact on overnight metabolism without altering fat oxidation [46-51]. Groen et al. was the first to show, in a proof-of-concept study, that pre-sleep dietary protein is well digested and absorbed, resulting in an increased overnight net protein balance in elderly adults [52]. Follow-up studies in younger populations provided further support [53]. The hyper-aminoacidemia from pre-sleep protein resulted in an increase in overnight muscle protein synthesis [52,54]. When previous evening exercise is performed, greater amounts of amino acids from pre-sleep dietary protein are incorporated into myofibrillar protein [55], resulting in an augmented muscle protein synthetic response [53]. While no optimal dose has been determined for pre-sleep protein consumption, $30 \mathrm{~g}$ of casein, with or without 2 
$\mathrm{g}$ of free leucine, increased net muscle protein balance without influencing post-exercise fractional synthetic rate (FSR) overnight [56]. However, Res et al. showed an increase of $\sim 22 \%$ in mixed muscle FSR when $40 \mathrm{~g}$ of pre-sleep casein protein was consumed compared to placebo following an acute bout of lower-body resistance training in young, recreationally active males [53]. Furthermore, no alterations in sleep quality with pre-sleep protein ingestion were reported [56-58]. Using microdialysis, no alterations in overnight fat metabolism with pre-sleep protein ingestion in males [59] or trained females [58] were found. Overall, acute studies support that pre-sleep protein represents an additional opportunity to stimulate the synthetic response without a detriment to fat metabolism.

\subsection{Long Term}

While most studies have shown benefits with sufficient doses of pre-sleep protein alone and in conjunction with evening exercise, fewer studies exist for chronic pre-sleep protein consumption with mixed results. van Loon's group were the first to show that a pre-sleep protein ( $27.5 \mathrm{~g}$ casein) and carbohydrate (15 g) beverage led to greater muscle strength gains and $10 \%$ increase in quadriceps cross-sectional area compared to a $\sim 6 \%$ increase in the non-caloric placebo $(p<0.05)$ in recreationally active young men after 12 weeks of whole-body resistance training performed in the evening [60]. In contrast, Vangsoe et al. reported no improvements for strength or body composition in active young males when $0.4 \mathrm{~g} / \mathrm{kg}$ insect protein ( $32 \mathrm{~g}$ on average) was ingested pre-sleep compared to iso-energetic $\mathrm{CHO}$ following 8 weeks of whole-body resistance training [61]. Interestingly, both studies reported relative protein intakes (means between $1.3-1.6 \mathrm{~g} / \mathrm{kg} / \mathrm{d}$ prior to supplementation) well above the RDA and within previously suggested optimal ranges [62] despite not providing standardized nutrition during the training intervention. Snijders et al. performed resistance training in the evening hours [60]. Though exercise time was not controlled in the Vangsoe et al. study, the authors indicated most performed their exercise sessions in the afternoon. This methodological difference in exercise time, and therefore proximity of pre-sleep protein ingestion to the exercise bout may explain discrepancy in findings. However, in both of these studies, participants were not in nitrogen balance and, consequently, the protein-supplemented groups consumed greater relative protein intakes compared to the control groups. In order to determine whether pre-sleep protein is advantageous or simply consuming greater daily protein is key, Antonio et al. reported no difference between morning (prior to $1200 \mathrm{~h}$ ) or night-time ( $\leq 90 \mathrm{~min}$ pre-sleep) protein intake ( $54 \mathrm{~g}$ casein) on body composition or strength outcomes following 8 weeks of strength training in trained males and females [63]. In a similar study design, Joy et al. reported no difference between 10 weeks of morning and pre-sleep casein on muscle size or strength in recreationally active males [64]. In contrast, casein consumed in the morning $(1000 \mathrm{~h})$ and evening $(2230 \mathrm{~h})$ improved fat-free mass to a greater extent than morning $(1000 \mathrm{~h})$ and afternoon ( $1550 \mathrm{~h}$ ) in high school-aged boys performing resistance exercise [65]. At this time, it is not entirely clear how significant timing is regarding changes in body composition.

\subsection{Exercise Timing}

Recently, investigators have shown benefits of pre-sleep protein on muscle recovery following evening exercise $[66,67]$. Using a cross-over design, West et al. provided $25 \mathrm{~g}$ of a whey protein blend or energy matched carbohydrate $(\mathrm{CHO})$ to young, resistance-trained males following whole-body resistance training. During the $24 \mathrm{~h}$ recovery period, net protein balance was improved and there was a moderate beneficial effect on maximal voluntary contraction, repetitions to failure, and Wingate peak power [66]. Similarly, Abbott et al. utilized a cross-over design and provided $40 \mathrm{~g}$ of pre-sleep casein or $\mathrm{CHO}$ to professional soccer players following night-time soccer matches. There was no clear difference in external loads between matches. In the $12 \mathrm{~h}$ recovery period, casein most likely improved reactive strength index, muscle soreness, and counter movement jump (CMJ) with likely beneficial effects at $36 \mathrm{~h}$ post-exercise for $\mathrm{CMJ}$ and most likely beneficial effects at $36 \mathrm{~h}$ for reactive strength index performance [67]. Others have challenged the efficacy of pre-sleep protein $[63,64,68-70]$ on muscular adaptations and performance. When exercise is performed in the morning, no benefits are reported for 
pre-sleep protein [68-70]. Of the three studies utilizing morning exercise and pre-sleep protein, two used trained populations for their investigation. Apweiler et al. had young, active males and females perform 100 drop jumps in the morning (0730-0930 h) to induce muscle damage, then consume either $40 \mathrm{~g}$ pre-sleep casein or $\mathrm{CHO} 30 \mathrm{~min}$ before bed. As expected, the muscle damaging protocol induced muscle soreness and reduced pain pressure threshold, maximal isometric voluntary contraction (MIVC), and CMJ, indicating muscle damage. However, there were no differences between groups or sexes for any measure [70]. Similarly, in order to mimic an endurance training camp, Larsen et al. had 32 trained runners perform 11 exercise bouts during a 1 week period while consuming $0.5 \mathrm{~g} / \mathrm{kg}(\sim 37 \mathrm{~g})$ of either whey protein isolate or $\mathrm{CHO}$ each night before bed. Standardized nutrition was provided by the researchers with protein for both groups set at $1.8 \mathrm{~g} / \mathrm{kg}$. Thus, protein supplementation was provided hours after the training stimulus. Again, no benefit was observed for time trial performance, training volume, or blood biomarkers between groups [68].

While pre-sleep protein seems to improve recovery from late-evening exercise, there does not seem to be a benefit on next-day exercise performance [47,49]. Ormsbee et al. provided $355 \mathrm{~mL}$ of fat-free chocolate milk (12 g PRO, $30 \mathrm{~g} \mathrm{CHO)} \mathrm{or} \mathrm{non-nutritive} \mathrm{placebo} 30$ min pre-sleep to trained female runners and triathletes in a double-blind, cross-over design. This study observed most likely trivial improvements in next-day $10 \mathrm{~km}$ time trial performance between treatments [47]. It is important to note that they used a low-calorie and low-protein option for pre-sleep feeding, which likely contributed to the null findings. Similarly, in a double-blind cross-over study, Madzima et al. [49] provided non-nutritive placebo, $24 \mathrm{~g}$, and $48 \mathrm{~g}$ of pre-sleep casein and whey to active, young women for a total of five treatment conditions. These authors reported no clear effects of any type or dose of pre-sleep protein compared to placebo on next-morning resistance exercise volume. However, the effects of pre-sleep protein ingestion on next-day performance in men is presently unknown. The work to date on pre-sleep protein feeding has all utilized animal-based protein. Given the rise in popularity of plant-based proteins, more research is required to investigate the effects of these proteins consumed pre-sleep. It has been suggested that combining plant-based proteins may overcome any essential amino acid deficiencies and therefore provide a complete amino acid profile [71] similar to animal-based protein [72]. Future work should compare pre-sleep animal-based protein with combinations of plant-based protein sources.

\section{Protein and Bone in Young, Exercising Individuals}

It is well established that an increase in habitual dietary protein intake (including supplementation) above the dietary RDA $(0.8 \mathrm{~g} / \mathrm{kg} / \mathrm{d})$ has a beneficial effect on muscle mass and muscle performance [42]. However, the potential beneficial effects of increased protein intake on properties of bone are less clear.

Proteins comprise approximately 30-50\% of bone mass and volume [73] and may play a crucial role in bone accretion and bone strength over time [74]. In summarizing several meta-analyses and review articles, a report endorsed by the European Society for Clinical and Economical Aspects of Osteoporosis, Osteoarthritis, and Musculoskeletal Diseases concluded that increasing dietary protein intake was associated with an increase in bone mineral density and a reduction in hip fracture risk [75]. While the mechanisms explaining the potential beneficial effects of protein on bone remain to be determined, protein influences calcium kinetics, growth factors and hormones, and muscle mass [76]. Increasing protein consumption typically increases calcium excretion due to improved intestinal calcium absorption but has no negative effect on calcium homeostasis [77]. An increase in calcium absorption would theoretically decrease parathyroid hormone secretion which would subsequently increase blood calcium levels and have a favorable effect on net bone accrual by suppressing bone resorption. Furthermore, increasing amino acid uptake increases collagen synthesis and osteocalcin expression, leading to a positive effect on osteoblast differentiation (cells involved in bone formation) [78]. In addition to calcium kinetics, protein augments insulin-like growth factor 1, a growth factor highly involved in bone growth $[77,78]$, and increases the release of incretin hormones which have anabolic effects on bone mass and microarchitecture (bone strength) [79]. Furthermore, it is well established that 
dietary protein ingestion increases the rates of muscle protein synthesis, which could lead to greater muscle accretion over time [42]. Greater muscle mass may increase mechanical strain on bone at their tendon attachment sites, leading to net bone accretion over time [80].

The vast majority of research investigating the effects of dietary protein consumption on properties of bone have focused on aging adults and disease state populations. Very limited research exists regarding younger exercising individuals. This focus area is important because exercising individuals are at a greater risk of developing/acquiring stress fractures [81] possibly due to an imbalance between bone resorption and bone formation caused by prolonged or high-intensity exercise [82], which over time may negatively influence training frequency, duration and progression. Therefore, strategies which increase bone mass and strength and subsequently decrease the prevalence of stress fractures are important for exercising individuals.

Research is mixed regarding the efficacy of increased dietary protein consumption (including supplementation) on properties of bone in exercising individuals. Male endurance runners ( $28 \pm 6 \mathrm{yr}$; $\geq 2$ years of experience) who consumed a protein-containing beverage $(0.5 \mathrm{~g} / \mathrm{kg} / \mathrm{d})$ immediately after exercise (treadmill run time to exhaustion at $75 \% \mathrm{VO}_{2}$ max) experienced a reduction in C-terminal telopeptides of type I collagen by $22-61 \%$ (indicator of bone resorption) and an increase in N-terminal propeptides of type I procollagen by $1-3 \%$ (indicator of bone formation), thereby creating a net positive bone turnover balance [82]. Similarly, in young swimmers (11-17 yr; $\geq 1$ year of training and competition experience), post-exercise whey protein ingestion $(2 \times 0.3 \mathrm{~g} / \mathrm{kg} / \mathrm{d})$ significantly decreased an indicator of bone resorption by $22 \%$ (carboxy-terminal collage cross-links) compared to a carbohydrate-based placebo. Protein ingestion had no effect on procollagen type 1 intact N-terminal propeptide levels (indicator of bone formation) [83]. In examining the effects of low (14\%) and high $(44 \%)$ whey protein supplementation (consumed immediately before and after whole-body resistance training sessions) for 12 weeks (3x/week) in collegiate male baseball players ( 20 years of age; $>10$ years of training experience), Chung et al. observed a significant increase in humerus bone mineral density in the dominant limb from high protein consumption only (high-protein: pre $1.34 \pm 0.03 \mathrm{~g} / \mathrm{cm}^{2}$, post $1.37 \pm 0.02 \mathrm{~g} / \mathrm{cm}^{2}, 2.2 \%$; low-protein: pre $1.32 \pm 0.03 \mathrm{~g} / \mathrm{cm}^{2}$, post $1.33 \pm 0.03 \mathrm{~g} / \mathrm{cm}^{2}, 0.8 \%$; $p<0.05$ ) [84]. However, there was no effect from protein, independent of dosage, on whole-body bone mineral density. Furthermore, there was no evidence of a deleterious effect from protein on bone. Higher intake of dairy-based protein food products (i.e., milk) was associated with a reduced rate of stress fractures in trained young female cross-country athletes who ran approximately 40 miles per week [85]. Milk ingestion was also a significant predictor of hip bone mineral density and whole-body bone mineral content accrual. It is important to note that dairy-based protein food products contain, in addition to protein, calcium, vitamin D, carbohydrates and fats. Interestingly, animal protein intake predicted gains in whole-body bone mineral density and content. The authors speculate that the beneficial effects from dairy-based protein food products on bone density may be reflective of the animal protein content (i.e., $47 \%$ of animal protein per day came from dairy consumption) [86]. In examining the effects of high protein consumption (habitual dietary consumption and/or supplementation; $2.8 \mathrm{~g} / \mathrm{kg} / \mathrm{d}$ or $\sim 169 \pm 55 \mathrm{~g} / \mathrm{d})$ vs. habitual dietary protein consumption $(1.5 \mathrm{~g} / \mathrm{kg} / \mathrm{d}$ or $\sim 91 \pm 17 \mathrm{~g} / \mathrm{d})$ in young females $(\sim 36 \mathrm{yr})$ who had been performing resistance and/or aerobic exercise $3 x /$ week for $\geq 1$ year, Antonio et al. found no effect (anabolic or deleterious) from additional dietary protein on whole-body bone mineral density (high protein: pre $1.25 \pm 0.11 \mathrm{~g} / \mathrm{cm}^{2}$, post $1.24 \pm 0.101 \mathrm{~g} / \mathrm{cm}^{2}$; habitual protein: pre $1.22 \pm 0.08 \mathrm{~g} / \mathrm{cm}^{2}$, post $1.22 \pm 0.09 \mathrm{~g} / \mathrm{cm}^{2}$ ) or content (high protein: pre $2.55 \pm 0.38 \mathrm{~kg}$, post $2.53 \pm 0.40 \mathrm{~kg}$; habitual protein: pre $2.47 \pm 0.35 \mathrm{~kg}$, post $2.47 \pm 0.34 \mathrm{~kg}$ ) after 6 months [87]. After 12 months, high protein consumption $\left(2.3 \mathrm{~g} \cdot \mathrm{kg}^{-1} \cdot \mathrm{d}^{-1}\right)$ still had no effect (anabolic or deleterious) on whole-body bone mineral density $\left(1.21 \pm 0.09 \mathrm{~g} / \mathrm{cm}^{2}\right)$ or content $(2.4 \pm 0.3 \mathrm{~kg})$. [88]. Finally, whey $(40 \mathrm{~g})$ and casein $(8 \mathrm{~g})$ protein supplementation during 10 weeks of high-intensity resistance training in trained young males (defined as performing $>3 \mathrm{~h}$ of resistance training per week for $>1$ year) had no effect on whole-body bone mineral content (protein: pre $2.452 .4 \pm 0.4 \mathrm{~kg}$, post $2.47 \pm 0.4 \mathrm{~kg}$; placebo: pre $2.54 \pm 0.5 \mathrm{~kg}$, post $2.55 \pm 0.6 \mathrm{~kg}$ ) [31]. 
Collectively, limited research indicates that protein supplementation can positively influence bone turnover and regional bone mineral in some exercising individuals. Increasing habitual dietary protein intake above the recommended daily allowance of $0.8 \mathrm{~g} / \mathrm{kg} / \mathrm{d}$ has no deleterious effects on bone in exercising individuals. Future research should investigate the long-term effects of dietary protein, with and without exercise training, on bone mineral, strength and geometric measures in exercising individuals.

\section{Conclusions}

It is evident that total protein intake is an important factor for any alteration in body composition. Based on the current evidence, protein intakes that far exceed the RDA may promote additional gains in lean body mass as well as a decrement in fat mass. However, in order to best achieve a gain in lean body mass or loss of fat mass, this is best achieved when complimented with a rigorous resistance training program. The role of pre-sleep protein feedings is not entirely understood. Nonetheless, pre-sleep feedings may be beneficial to athletes inasmuch as it contributes to total daily protein intake. To date, higher protein intakes tend to have a neutral effect on bone mineral density; however, there is evidence to suggest that it can indeed have a positive effect.

Author Contributions: Conceptualization, J.A., D.G.C., M.J.O. and J.R.; writing-original draft preparation, J.A., D.G.C., S.C.F., M.J.O., P.G.S., and J.R.; writing—review and editing, J.A., D.G.C., S.C.F., M.J.O., P.G.S., and J.R. All authors have read and agreed to the published version of the manuscript.

Funding: This research received no external funding.

Conflicts of Interest: M.J.O. serves on the Dymatize Scientific Advisory Board, a company that sells creatine in its supplement portfolio but was not used in this study. J.A. is the CEO and co-founder of the ISSN. The ISSN is supported in part by grants from raw good suppliers and branded companies that sell dietary protein supplements. All other authors declare no conflict of interest.

\section{References}

1. Grover, Z.; Ee, L.C. Protein energy malnutrition. Pediatr. Clin. 2009, 56, 1055-1068. [CrossRef]

2. Antonio, J. High-protein diets in trained individuals. Res. Sports. Med. 2019, 27, 195-203. [CrossRef]

3. Kreider, R.B.; Campbell, B. Protein for exercise and recovery. Phys. Sportsmed. 2009, 37, 13-21. [CrossRef]

4. Lemon, P.W. Protein and exercise: Update 1987. Med. Sci. Sports Exerc. 1987, 19, S179-S190. [CrossRef]

5. Lemon, P.W. Effect of exercise on protein requirements. J. Sports Sci. 1991, 9, 53-70. [CrossRef]

6. Lemon, P.W. Do athletes need more dietary protein and amino acids? Int. J. Sport Nutr. 1995, 5, S39-S61. [CrossRef]

7. Phillips, S.M. Dietary protein requirements and adaptive advantages in athletes. Br. J. Nutr. 2012, 108, S158-S167. [CrossRef]

8. Von Liebig, J.F. Animal Chemistry; Taylor and Walton: Luton, UK, 1842.

9. Jager, R.; Kerksick, C.M.; Campbell, B.I.; Cribb, P.J.; Wells, S.D.; Skwiat, T.M.; Purpura, M.; Ziegenfuss, T.N.; Ferrando, A.A.; Arent, S.M.; et al. International Society of Sports Nutrition Position Stand: Protein and exercise. J. Int. Soc. Sports Nutr. 2017, 14, 20. [CrossRef]

10. Lemon, P.W. Protein and amino acid needs of the strength athlete. Int. J. Sport Nutr. 1991, 1, 127-145. [CrossRef]

11. Lemon, P.W. Protein requirements of soccer. J. Sports Sci. 1994, 12, S17-S22. [CrossRef]

12. Gontzea, I.; Sutzesco, P.; Dumitrache, S. Research on the protein requirement of man during muscular activity. Arch. Sci. Physiol. 1962, 16, 97-120.

13. Amamou, T.; Normandin, E.; Pouliot, J.; Dionne, I.J.; Brochu, M.; Riesco, E. Effect of a High-Protein Energy-Restricted Diet Combined with Resistance Training on Metabolic Profile in Older Individuals with Metabolic Impairments. J. Nutr. Health Aging 2017, 21, 67-74. [CrossRef]

14. Brinkworth, G.D.; Noakes, M.; Parker, B.; Foster, P.; Clifton, P.M. Long-term effects of advice to consume a high-protein, low-fat diet, rather than a conventional weight-loss diet, in obese adults with type 2 diabetes: One-year follow-up of a randomised trial. Diabetologia 2004, 47, 1677-1686. [CrossRef] 
15. Farnsworth, E.; Luscombe, N.D.; Noakes, M.; Wittert, G.; Argyiou, E.; Clifton, P.M. Effect of a high-protein, energy-restricted diet on body composition, glycemic control, and lipid concentrations in overweight and obese hyperinsulinemic men and women. Am. J. Clin. Nutr. 2003, 78, 31-39. [CrossRef]

16. Wycherley, T.P.; Buckley, J.D.; Noakes, M.; Clifton, P.M.; Brinkworth, G.D. Comparison of the effects of weight loss from a high-protein versus standard-protein energy-restricted diet on strength and aerobic capacity in overweight and obese men. Eur. J. Nutr. 2013, 52, 317-325. [CrossRef]

17. Bray, G.A.; Redman, L.M.; de Jonge, L.; Covington, J.; Rood, J.; Brock, C.; Mancuso, S.; Martin, C.K.; Smith, S.R. Effect of protein overfeeding on energy expenditure measured in a metabolic chamber. Am. J. Clin. Nutr. 2015, 101, 496-505. [CrossRef]

18. Teske, J.A.; Billington, C.J.; Kotz, C.M. Neuropeptidergic mediators of spontaneous physical activity and non-exercise activity thermogenesis. Neuroendocrinology 2008, 87, 71-90. [CrossRef]

19. Levine, J.A.; Vander Weg, M.W.; Hill, J.O.; Klesges, R.C. Non-exercise activity thermogenesis: The crouching tiger hidden dragon of societal weight gain. Arterioscler. Thromb. Vasc. Biol. 2006, 26, 729-736. [CrossRef]

20. Swaminathan, R.; King, R.F.; Holmfield, J.; Siwek, R.A.; Baker, M.; Wales, J.K. Thermic effect of feeding carbohydrate, fat, protein and mixed meal in lean and obese subjects. Am. J. Clin. Nutr. 1985, 42, 177-181. [CrossRef]

21. Binns, A.; Gray, M.; Di Brezzo, R. Thermic effect of food, exercise, and total energy expenditure in active females. J. Sci. Med. Sport 2015, 18, 204-208. [CrossRef]

22. Oikawa, S.Y.; Kamal, M.J.; Webb, E.K.; McGlory, C.; Baker, S.K.; Phillips, S.M. Whey protein but not collagen peptides stimulate acute and longer-term muscle protein synthesis with and without resistance exercise in healthy older women: A randomized controlled trial. Am. J. Clin. Nutr. 2020, 111, 708-718. [CrossRef]

23. Kim, I.Y.; Schutzler, S.; Schrader, A.; Spencer, H.J.; Azhar, G.; Ferrando, A.A.; Wolfe, R.R. The anabolic response to a meal containing different amounts of protein is not limited by the maximal stimulation of protein synthesis in healthy young adults. Am. J. Physio.l Endocrinol. Metab. 2016, 310, E73-E80. [CrossRef]

24. Luiking, Y.C.; Deutz, N.E.; Memelink, R.G.; Verlaan, S.; Wolfe, R.R. Postprandial muscle protein synthesis is higher after a high whey protein, leucine-enriched supplement than after a dairy-like product in healthy older people: A randomized controlled trial. Nutr. J. 2014, 13, 9. [CrossRef]

25. Tipton, K.D.; Elliott, T.A.; Cree, M.G.; Aarsland, A.A.; Sanford, A.P.; Wolfe, R.R. Stimulation of net muscle protein synthesis by whey protein ingestion before and after exercise. Am. J. Physiol. Endocrinol. Metab. 2007, 292, E71-E76. [CrossRef]

26. Elliot, T.A.; Cree, M.G.; Sanford, A.P.; Wolfe, R.R.; Tipton, K.D. Milk ingestion stimulates net muscle protein synthesis following resistance exercise. Med. Sci. Sports Exerc. 2006, 38, 667-674. [CrossRef]

27. Paddon-Jones, D.; Sheffield-Moore, M.; Zhang, X.J.; Volpi, E.; Wolf, S.E.; Aarsland, A.; Ferrando, A.A.; Wolfe, R.R. Amino acid ingestion improves muscle protein synthesis in the young and elderly. Am. J. Physiol. Endocrinol. Metab. 2004, 286, E321-E328. [CrossRef]

28. Tipton, K.D.; Ferrando, A.A.; Phillips, S.M.; Doyle, D., Jr.; Wolfe, R.R. Postexercise net protein synthesis in human muscle from orally administered amino acids. Am. J. Physiol. 1999, 276, E628-E634. [CrossRef]

29. Volpi, E.; Ferrando, A.A.; Yeckel, C.W.; Tipton, K.D.; Wolfe, R.R. Exogenous amino acids stimulate net muscle protein synthesis in the elderly. J. Clin. Invest. 1998, 101, 2000-2007. [CrossRef]

30. Mitchell, C.J.; Churchward-Venne, T.A.; Parise, G.; Bellamy, L.; Baker, S.K.; Smith, K.; Atherton, P.J.; Phillips, S.M. Acute post-exercise myofibrillar protein synthesis is not correlated with resistance training-induced muscle hypertrophy in young men. PLoS ONE 2014, 9, e89431. [CrossRef]

31. Kerksick, C.M.; Rasmussen, C.J.; Lancaster, S.L.; Magu, B.; Smith, P.; Melton, C.; Greenwood, M.; Almada, A.L.; Earnest, C.P.; Kreider, R.B. The effects of protein and amino acid supplementation on performance and training adaptations during ten weeks of resistance training. J. Strength Cond. Res. 2006, 20, 643-653. [CrossRef]

32. Ormsbee, M.J.; Willingham, B.D.; Marchant, T.; Binkley, T.L.; Specker, B.L.; Vukovich, M.D. Protein Supplementation During a 6-Month Concurrent Training Program: Effect on Body Composition and Muscular Strength in Sedentary Individuals. Int. J. Sport Nutr. Exerc. Metab. 2018, 28, 619-628. [CrossRef]

33. Antonio, J.; Peacock, C.A.; Ellerbroek, A.; Fromhoff, B.; Silver, T. The effects of consuming a high protein $\operatorname{diet}(4.4 \mathrm{~g} / \mathrm{kg} / \mathrm{d})$ on body composition in resistance-trained individuals. J. Int. Soc. Sports Nutr. 2014, 11, 19. [CrossRef] 
34. Antonio, J.; Ellerbroek, A.; Silver, T.; Orris, S.; Scheiner, M.; Gonzalez, A.; Peacock, C.A. A high protein diet $(3.4 \mathrm{~g} / \mathrm{kg} / \mathrm{d})$ combined with a heavy resistance training program improves body composition in healthy trained men and women-a follow-up investigation. J. Int. Soc. Sports Nutr. 2015, 12, 39. [CrossRef]

35. Campbell, B.I.; Aguilar, D.; Conlin, L.; Vargas, A.; Schoenfeld, B.J.; Corson, A.; Gai, C.; Best, S.; Galvan, E.; Couvillion, K. Effects of High Versus Low Protein Intake on Body Composition and Maximal Strength in Aspiring Female Physique Athletes Engaging in an 8-Week Resistance Training Program. Int. J. Sport Nutr. Exerc. Metab. 2018, 28, 580-585. [CrossRef]

36. Ten Haaf, D.S.M.; Eijsvogels, T.M.H.; Bongers, C.; Horstman, A.M.H.; Timmers, S.; de Groot, L.; Hopman, M.T.E. Protein supplementation improves lean body mass in physically active older adults: A randomized placebo-controlled trial. J. Cachexia Sarcopenia Muscle 2019, 10, 298-310. [CrossRef]

37. Lemon, P.W.; Tarnopolsky, M.A.; MacDougall, J.D.; Atkinson, S.A. Protein requirements and muscle mass/strength changes during intensive training in novice bodybuilders. J. Appl. Physiol. 1992, 73, 767-775. [CrossRef]

38. Antonio, J.; Ellerbroek, A.; Silver, T.; Vargas, L.; Peacock, C. The effects of a high protein diet on indices of health and body composition-a crossover trial in resistance-trained men. J. Int. Soc. Sports Nutr. 2016, 13, 3. [CrossRef]

39. Antonio, J.; Ellerbroek, A.; Silver, T.; Vargas, L.; Tamayo, A.; Buehn, R.; Peacock, C.A. A High Protein Diet Has No Harmful Effects: A One-Year Crossover Study in Resistance-Trained Males. J. Nutr. Metab. 2016, 2016, 9104792. [CrossRef]

40. Spillane, M.; Willoughby, D.S. Daily Overfeeding from Protein and/or Carbohydrate Supplementation for Eight Weeks in Conjunction with Resistance Training Does not Improve Body Composition and Muscle Strength or Increase Markers Indicative of Muscle Protein Synthesis and Myogenesis in Resistance-Trained Males. J. Sports Sci. Med. 2016, 15, 17-25.

41. Hoffman, J.R.; Ratamess, N.A.; Kang, J.; Falvo, M.J.; Faigenbaum, A.D. Effect of protein intake on strength, body composition and endocrine changes in strength/power athletes. J. Int. Soc. Sports Nutr. 2006, 3, $12-18$. [CrossRef]

42. Morton, R.W.; Murphy, K.T.; McKellar, S.R.; Schoenfeld, B.J.; Henselmans, M.; Helms, E.; Aragon, A.A.; Devries, M.C.; Banfield, L.; Krieger, J.W.; et al. A systematic review, meta-analysis and meta-regression of the effect of protein supplementation on resistance training-induced gains in muscle mass and strength in healthy adults. Br. J. Sports Med. 2018, 52, 376-384. [CrossRef] [PubMed]

43. Trommelen, J.; van Loon, L.J. Pre-Sleep Protein Ingestion to Improve the Skeletal Muscle Adaptive Response to Exercise Training. Nutrients 2016, 8, 763. [CrossRef] [PubMed]

44. Snijders, T.; Trommelen, J.; Kouw, I.W.K.; Holwerda, A.M.; Verdijk, L.B.; van Loon, L.J.C. The Impact of Pre-sleep Protein Ingestion on the Skeletal Muscle Adaptive Response to Exercise in Humans: An Update. Front. Nutr. 2019, 6, 17. [CrossRef] [PubMed]

45. Kinsey, A.W.; Ormsbee, M.J. The health impact of nighttime eating: Old and new perspectives. Nutrients 2015, 7, 2648-2662. [CrossRef] [PubMed]

46. Ormsbee, M.J.; Kinsey, A.W.; Eddy, W.R.; Madzima, T.A.; Arciero, P.J.; Figueroa, A.; Panton, L.B. Corrigendum: The influence of nighttime feeding of carbohydrate or protein combined with exercise training on appetite and cardiometabolic risk in young obese women. Appl. Physiol. Nutr. Metab. 2019, 44, 228. [CrossRef]

47. Ormsbee, M.J.; Gorman, K.A.; Miller, E.A.; Baur, D.A.; Eckel, L.A.; Contreras, R.J.; Panton, L.B.; Spicer, M.T. Nighttime feeding likely alters morning metabolism but not exercise performance in female athletes. Appl. Physiol. Nutr. Metab. 2016, 41, 719-727. [CrossRef]

48. Madzima, T.A.; Panton, L.B.; Fretti, S.K.; Kinsey, A.W.; Ormsbee, M.J. Night-time consumption of protein or carbohydrate results in increased morning resting energy expenditure in active college-aged men. Br. J. Nutr. 2014, 111, 71-77. [CrossRef]

49. Madzima, T.A.; Melanson, J.T.; Black, J.R.; Nepocatych, S. Pre-Sleep Consumption of Casein and Whey Protein: Effects on Morning Metabolism and Resistance Exercise Performance in Active Women. Nutrients 2018, 10, 1273. [CrossRef]

50. Leyh, S.M.; Willingham, B.D.; Baur, D.A.; Panton, L.B.; Ormsbee, M.J. Pre-sleep protein in casein supplement or whole-food form has no impact on resting energy expenditure or hunger in women. Br. J. Nutr. 2018, 120, 988-994. [CrossRef] 
51. Lay, A.H.H.; Crabtree, D.R.; Campbell, T.G.; Dreczkowski, G.M.; Galloway, S.D.R.; Tipton, K.D.; Witard, O.C. A bedtime milk snack does not impact RMR, substrate utilisation and appetite the following morning in mildly overweight males. Br. J. Nutr. 2018, 119, 1355-1365. [CrossRef]

52. Groen, B.B.; Res, P.T.; Pennings, B.; Hertle, E.; Senden, J.M.; Saris, W.H.; van Loon, L.J.C. Intragastric protein administration stimulates overnight muscle protein synthesis in elderly men. Am. J. Physiol. Endocrinol. Metab. 2012, 302, E52-E60. [CrossRef] [PubMed]

53. Res, P.T.; Groen, B.; Pennings, B.; Beelen, M.; Wallis, G.A.; Gijsen, A.P.; Senden, J.M.G.; Van Loon, L.J.C. Protein ingestion before sleep improves postexercise overnight recovery. Med. Sci. Sports Exerc. 2012, 44, 1560-1569. [CrossRef] [PubMed]

54. Kouw, I.W.; Holwerda, A.M.; Trommelen, J.; Kramer, I.F.; Bastiaanse, J.; Halson, S.L.; Wodzig, W.K.; Verdijk, L.B.; van Loon, L.J.C. Protein Ingestion before Sleep Increases Overnight Muscle Protein Synthesis Rates in Healthy Older Men: A Randomized Controlled Trial. J. Nutr. 2017, 147, 2252-2261. [CrossRef] [PubMed]

55. Trommelen, J.; Holwerda, A.M.; Kouw, I.W.; Langer, H.; Halson, S.L.; Rollo, I.; Verdijk, L.B.; LJ, V.A.N.L. Resistance Exercise Augments Postprandial Overnight Muscle Protein Synthesis Rates. Med. Sci. Sports Exerc. 2016, 48, 2517-2525. [CrossRef]

56. Trommelen, J.; Kouw, I.W.K.; Holwerda, A.M.; Snijders, T.; Halson, S.L.; Rollo, I.; Verdijk, L.B.; van Loon, L.J.C. Presleep dietary protein-derived amino acids are incorporated in myofibrillar protein during postexercise overnight recovery. Am. J. Physiol. Endocrinol. Metab. 2018, 314, E457-E467. [CrossRef]

57. Holwerda, A.M.; Kouw, I.W.; Trommelen, J.; Halson, S.L.; Wodzig, W.K.; Verdijk, L.B.; van Loon, L.J. Physical Activity Performed in the Evening Increases the Overnight Muscle Protein Synthetic Response to Presleep Protein Ingestion in Older Men. J. Nutr. 2016, 146, 1307-1314. [CrossRef]

58. Allman, B.R.; Morrissey, M.C.; Kim, J.S.; Panton, L.B.; Contreras, R.J.; Hickner, R.C.; Ormsbee, M.J. Lipolysis and Fat Oxidation Are Not Altered with Presleep Compared with Daytime Casein Protein Intake in Resistance-Trained Women. J. Nutr. 2020, 150, 47-54. [CrossRef]

59. Kinsey, A.W.; Cappadona, S.R.; Panton, L.B.; Allman, B.R.; Contreras, R.J.; Hickner, R.C.; Ormsbee, M.J. The Effect of Casein Protein Prior to Sleep on Fat Metabolism in Obese Men. Nutrients 2016, 8, 452. [CrossRef]

60. Snijders, T.; Res, P.T.; Smeets, J.S.; van Vliet, S.; van Kranenburg, J.; Maase, K.; Kies, A.K.; Verdijk, L.B.; van Loon, L.J. Protein Ingestion before Sleep Increases Muscle Mass and Strength Gains during Prolonged Resistance-Type Exercise Training in Healthy Young Men. J. Nutr. 2015, 145, 1178-1184. [CrossRef]

61. Vangsoe, M.T.; Joergensen, M.S.; Heckmann, L.L.; Hansen, M. Effects of Insect Protein Supplementation during Resistance Training on Changes in Muscle Mass and Strength in Young Men. Nutrients 2018, 10. [CrossRef]

62. Phillips, S.M.; Chevalier, S.; Leidy, H.J. Protein requirements beyond the RDA: Implications for optimizing health. Appl. Physiol. Nutr. Metab. 2016, 41, 565-572. [CrossRef] [PubMed]

63. Antonio, J.; Ellerbroek, A.; Peacock, C.; Silver, T. Casein Protein Supplementation in Trained Men and Women: Morning versus Evening. Int. J. Exerc. Sci. 2017, 10, 479-486. [PubMed]

64. Joy, J.M.; Vogel, R.M.; Shane Broughton, K.; Kudla, U.; Kerr, N.Y.; Davison, J.M.; Wildman, R.E.C.; DiMarco, N.M. Daytime and nighttime casein supplements similarly increase muscle size and strength in response to resistance training earlier in the day: A preliminary investigation. J. Int. Soc. Sports. Nutr. 2018, 15, 24. [CrossRef] [PubMed]

65. Burk, A.; Timpmann, S.; Medijainen, L.; Vahi, M.; Oopik, V. Time-divided ingestion pattern of casein-based protein supplement stimulates an increase in fat-free body mass during resistance training in young untrained men. Nutr. Res. 2009, 29, 405-413. [CrossRef]

66. West, D.W.D.; Abou Sawan, S.; Mazzulla, M.; Williamson, E.; Moore, D.R. Whey Protein Supplementation Enhances Whole Body Protein Metabolism and Performance Recovery after Resistance Exercise: A Double-Blind Crossover Study. Nutrients 2017, 9, 735. [CrossRef]

67. Abbott, W.; Brett, A.; Cockburn, E.; Clifford, T. Presleep Casein Protein Ingestion: Acceleration of Functional Recovery in Professional Soccer Players. Int. J. Sports Physiol. Perform. 2019, 14, 385-391. [CrossRef]

68. Larsen, M.S.; Clausen, D.; Jorgensen, A.A.; Mikkelsen, U.R.; Hansen, M. Presleep Protein Supplementation Does Not Improve Recovery During Consecutive Days of Intense Endurance Training: A Randomized Controlled Trial. Int. J. Sport Nutr. Exerc. Metab. 2019, 29, 426-434. [CrossRef] 
69. Holwerda, A.M.; Overkamp, M.; Paulussen, K.J.M.; Smeets, J.S.J.; van Kranenburg, J.; Backx, E.M.P.; Gijsen, A.P.; Goessens, J.P.B.; Verdijk, L.B.; van Loon, L.J.C. Protein Supplementation after Exercise and before Sleep Does Not Further Augment Muscle Mass and Strength Gains during Resistance Exercise Training in Active Older Men. J. Nutr. 2018, 148, 1723-1732. [CrossRef]

70. Apweiler, E.; Wallace, D.; Stansfield, S.; Allerton, D.M.; Brown, M.A.; Stevenson, E.J.; Clifford, T. Pre-Bed Casein Protein Supplementation Does Not Enhance Acute Functional Recovery in Physically Active Males and Females When Exercise is Performed in the Morning. Sports 2018, 7, 5. [CrossRef]

71. Gorissen, S.H.M.; Witard, O.C. Characterising the muscle anabolic potential of dairy, meat and plant-based protein sources in older adults. Proc. Nutr. Soc. 2018, 77, 20-31. [CrossRef]

72. Gorissen, S.H.M.; Crombag, J.J.R.; Senden, J.M.G.; Waterval, W.A.H.; Bierau, J.; Verdijk, L.B.; van Loon, L.J.C. Protein content and amino acid composition of commercially available plant-based protein isolates. Amino Acids 2018, 50, 1685-1695. [CrossRef] [PubMed]

73. Heaney, R.P.; Layman, D.K. Amount and type of protein influences bone health. Am. J. Clin. Nutr. 2008, 87, 1567S-1570S. [CrossRef] [PubMed]

74. Wallace, T.C.; Frankenfeld, C.L. Dietary Protein Intake above the Current RDA and Bone Health: A Systematic Review and Meta-Analysis. J. Am. Coll. Nutr. 2017, 36, 481-496. [CrossRef] [PubMed]

75. Rizzoli, R.; Biver, E.; Bonjour, J.P.; Coxam, V.; Goltzman, D.; Kanis, J.A.; Lappe, J.; Rejnmark, L.; Sahni, S.; Weaver, C.; et al. Benefits and safety of dietary protein for bone health-an expert consensus paper endorsed by the European Society for Clinical and Economical Aspects of Osteopororosis, Osteoarthritis, and Musculoskeletal Diseases and by the International Osteoporosis Foundation. Osteoporos. Int. 2018, 29, 1933-1948. [CrossRef]

76. Kerstetter, J.E.; Kenny, A.M.; Insogna, K.L. Dietary protein and skeletal health: A review of recent human research. Curr. Opin. Lipidol. 2011, 22, 16-20. [CrossRef]

77. Gaffney-Stomberg, E.; Insogna, K.L.; Rodriguez, N.R.; Kerstetter, J.E. Increasing dietary protein requirements in elderly people for optimal muscle and bone health. J. Am. Geriatr. Soc. 2009, 57, 1073-1079. [CrossRef]

78. MacDonell, R.; Hamrick, M.W.; Isales, C.M. Protein/amino-acid modulation of bone cell function. BoneKEy Rep . 2016, 5, 827. [CrossRef]

79. Mabilleau, G. Interplay between bone and incretin hormones: A review. Morphologie 2017, 101, 9-18. [CrossRef]

80. Chilibeck, P.D.; Sale, D.G.; Webber, C.E. Exercise and bone mineral density. Sports Med. 1995, 19, $103-122$. [CrossRef]

81. Fredericson, M.; Chew, K.; Ngo, J.; Cleek, T.; Kiratli, J.; Cobb, K. Regional bone mineral density in male athletes: A comparison of soccer players, runners and controls. Br. J. Sports Med. 2007, 41, 664-668. [CrossRef]

82. Townsend, R.; Elliott-Sale, K.J.; Currell, K.; Tang, J.; Fraser, W.D.; Sale, C. The Effect of Postexercise Carbohydrate and Protein Ingestion on Bone Metabolism. Med. Sci. Sports Exerc. 2017, 49, 1209-1218. [CrossRef] [PubMed]

83. Theocharidis, A.; McKinlay, B.J.; Vlachopoulos, D.; Josse, A.R.; Falk, B.; Klentrou, P. Effects of post exercise protein supplementation on markers of bone turnover in adolescent swimmers. J. Int. Soc. Sports Nutr. 2020, 17, 20. [CrossRef] [PubMed]

84. Chung, C.W.; Kuo, C.H.; Huang, H.Y.; Alkhatib, A.; Tseng, C.Y.; Huang, C.Y.; Kuo, C.H. High-protein supplementation facilitates weight training-induced bone mineralization in baseball players. Nutrition 2020, 75-76, 110760. [CrossRef] [PubMed]

85. Nattiv, A. Stress fractures and bone health in track and field athletes. J Sci Med Sport 2000, 3, 268-279. [CrossRef]

86. Nieves, J.W.; Melsop, K.; Curtis, M.; Kelsey, J.L.; Bachrach, L.K.; Greendale, G.; Sowers, M.F.; Sainani, K.L. Nutritional factors that influence change in bone density and stress fracture risk among young female cross-country runners. PM $R$ 2010, 2, 740-750. [CrossRef]

87. Antonio, J.; Ellerbroek, A.; Evans, C.; Silver, T.; Peacock, C.A. High protein consumption in trained women: Bad to the bone? J. Int. Soc. Sports Nutr. 2018, 15, 6. [CrossRef]

88. Antonio, J.; Ellerbroek, A.; Evans, C. The Effects of a High-Protein Diet on Bone Mineral Density in Exercise-Trained Women: A 1-Year Investigation. J. Funct. Morphol. Kinesiol. 2018, 3, 62. [CrossRef] 